\title{
Reformationsjubilæernes iscenesættelse af samhørighed mellem stat, kirke og folk i Danmark
}

\author{
MARGIT WARBURG
}

ENGLISH ABSTRACT: The 500th anniversary of the onset of the Lutheran reformation was celebrated in Denmark during most of 2017. Unlike the celebrations in Norway, Sweden and Germany, the Danish celebrations had a remarkable focus on the national significance of the Reformation. The celebrations ranged from large, state-sponsored national events to more than one thousand local arrangements involving civil society, educational institutions and parishes. This article analyses some of the historical Reformation jubilees in Denmark and compare them to fresh empirical material from the Danish Reformation jubilee in 2017. The analysis shows, among other things, that a recurrent theme in the celebrations was a claim of a special relationship between Denmark and God, which is a clear expression of Danish civil religion. Examples of civilreligious statements and activities are presented.

DANSK RESUMÉ: 500-års jubilæet for Reformationens begyndelse blev fejret $i$ Danmark gennem det meste af 2017. I modsætning til fejringerne i Norge, Sverige og Tyskland var de danske fejringer $i$ bemærkelsesværdig grad rettet mod reformationens nationale betydning. Fejringerne rakte fra store, statslige, nationale begivenheder til over et tusinde lokale arrangementer med deltagelse af civilsamfund, uddannelsesinstitutioner og kirkesogne. Denne artikel analyserer nogle af de historiske reformationsjubilæer og sammenligner dem med nyt empirisk materiale fra det danske reformationsjubilæum $i$ 2017. Analysen påviser blandt andet, at et gennemgående tema i fejringerne var en påstand om et særligt forhold mellem Danmark og Gud, hoad der klart er udtryk for dansk civilreligion. I artiklen bliver der givet eksempler på civilreligiøse udsagn og aktiviteter.

KEYWORDS: Reformation anniversary; Denmark; civil religion; anti-Catholicism; Luther; Grundtvig 
Markeringen af 500-året for reformationens begyndelse har i løbet af 2017 fyldt godt op i den danske offentlighed. Den danske stat og regering stod for flere officielle markeringer af reformationsjubilæet. Langt hovedparten af de mange arrangementer var dog lokalt forankret og var blevet til på lokalt initiativ, både inden for og uden for folkekirken. Ud over særlige gudstjenester har der været historiske optrin, udstillinger, foredrag og meget mere rundt om i landet.

Jeg har foretaget en optælling af de mange arrangementer, som har været annonceret på reformationsfejringens fælles portal, luther2017.dk, og er kommet til, at der var ca. 1100 endagsarrangementer ud over en lang række særudstillinger, som strakte sig over længere tid. Adskillige endagsarrangementer blev gentaget mange gange rundt om i landet, og derfor optrådte de samme arrangementer flere gange forskellige steder og på forskellige datoer på luther2017.dk. Der var altså ikke tale om 1100 unikke arrangementer, men dog 1100 muligheder for, at befolkningen kunne deltage i reformationsfejringen. Det er endda et minimumstal, for jeg ved, at langtfra alle arrangementer blev annonceret på luther2017.dk. ${ }^{1}$

I den brede offentlighed forblev reformationsjubilæet da heller ikke ubemærket. En repræsentativ spørgeskemaundersøgelse foretaget i efteråret 2017 viste, at ca. halvdelen af de udspurgte danskere vidste, at der fandt en særlig fejring af reformationen sted i løbet af året (Frederiksen \& Hansen 2017). Reformationsjubilæet i 2017 var således en begivenhed, hvor forholdet mellem stat, kirke og befolkning var i spil.

Reformationsjubilæet 2017 var selvfølgelig ikke kun en dansk begivenhed; også i andre europæiske lande med store lutherske kirker, såsom Norge, Sverige, og Tyskland, var der officielle markerringer af jubilæet. I Norge og Sverige var det den Norske Kirke og Svenska Kyrkan, der stod som arrangører. Her lagde man hovedvægten på reformationens konfessionelle betydning og tilstræbte en økumenisk profil i fejringerne. ${ }^{2}$ For eksempel var den norske kirkes hovedtema nåde, som var konkretiseret i tre undertemaer: 'Frelsen er ikke til salgs', 'Mennesker er ikke til salgs' og 'Skaperverket er ikke til salgs'. Valget af disse tre undertemaer er i øvrigt et tydeligt tegn på den norske kirkes stigende aktivisme, efter at dens bånd til den norske stat gradvist blev løsnet i perioden 2008 til 2017.

I Tyskland deltog forbundsregeringen sammen med en række delstatsregeringer i arbejdet med at markere jubilæumsåret. Der blev gjort meget ud af, at markeringen skulle være åben og international i modsætning til tidligere jubilæers nationale og konfessionelle ramme. ${ }^{3}$

I det selskab skilte det danske reformationsjubilæum sig ud ved at lægge stor vægt på reformationens nationale betydning i bred samfundsmæssig og kulturel forstand.

1 For eksempel har kirkehistorikeren Martin Schwarz Lausten holdt 106 foredrag om reformationen i 2017 (e-mail, den 25. marts 2018), nationaløkonomen Niels Kærgård har holdt 25 foredrag (e-mail, den 25. marts 2018), og nationaløkonomen Jørn Henrik Petersen har holdt 103 foredrag (e-mail, den 26. marts 2018). Kun et fåtal af disse 234 foredrag (under 20 i alt) var annonceret på luther2017.dk.

2 Oplysninger om reformationsfejringerne i Norge og Sverige kan hentes under kirkernes hjemmesider ved at søge videre på internet-adresserne: www.kirken.no/nb-NO/reformasjon-2017 og www.svenskakyrkan.se/church-of-swedens-focus-on-reformation-year-2017.

3 På forbundsregeringsniveau er indgangen www.reformationsjubilaeum-bund.de. Se herunder link til Bilanz der Bundesregierung. 
Det overordnede, koordinerende ansvar for fejringen af jubilæet var lagt $\mathrm{i}$ hænderne på et præsidium på i alt 12 medlemmer udpeget af regeringen; heraf var der kun ét medlem fra folkekirken, nemlig Københavns biskop. Resten af medlemmerne kom fra universitetsverdenen, museerne og kulturlivet. Hendes Majestæt Dronningen var protektor for reformationsfejringen. ${ }^{4}$

Præsidiets opgave var primært af koordinerende art, idet det var ambitionen, at planlægning og gennemførelse af de forskellige jubilæumsarrangementer skulle ske lokalt og med så bred deltagelse som muligt fra institutioner og civilsamfund. Præsidiets vigtigste værktøj var en interaktiv internetportal, Luther2017.dk, hvor de forskellige arrangementer kunne annonceres systematisk. Derudover havde præsidiet truffet aftale med Folkeuniversitetet i Aarhus om at arrangere forskellige landsdækkende formidlingsaktiviteter. Præsidiets funktionsperiode ophørte i øvrigt med udgangen af 2017; men portalen Luther2017.dk er i skrivende stund stadig tilgængelig.

Præsidiet fik det kommissorium "at fremme forståelsen af Reformationens betydning for det danske samfund, den danske kirke, dansk identitet og bevidsthed". Kommissoriet således mere end antyder, at den særlige danske tilgang til Lutheråret 2017 var en iscenesættelse af en samhørighed mellem stat, kirke og folk i Danmark.

Kommissoriets præmis, især den del, der henviser til reformationens betydning for den danske samfundsmodel og velfærdsstatens tilblivelse, har en vis opbakning i fagkredse (Knudsen 2000; Østergaard 2003; Kaspersen \& Lindvall 2008; Petersen \& Petersen 2009; Petersen 2017). Derimod rammer den del, som omhandler betydningen for dansk identitet og bevidsthed, ned i en større og vedvarende diskussion, som har delt vandene i den offentlige debat, også før 2017 (Nielsen 2011). Endelig har flere danske forskere, først og fremmest Frederik Stjernfelt (2017) og Jens-André Herbener (2017), rejst den generelle kritik, at Martin Luther og den tidlige reformation ikke kan tilskrives nogen afgørende betydning for den senere udvikling af det danske demokrati, kønnenes ligestilling, tolerance og andre lovpriste værdier, sådan som der har været tilløb til i den i øvrigt ret livlige debat i forbindelse med reformationsjubilæet. Det vil imidlertid føre for vidt at opsummere debatten her, idet hovedsigtet er at analysere vigtige konkrete eksempler på fejringer af reformationen i Danmark.

\section{Historisk brud eller kontinuitet?}

En af de oprindelige initiativtagere til markeringen af reformationsjubilæet i Danmark, kirkehistorikeren Carsten Bach-Nielsen fra Aarhus Universitet, har udgivet et stort og smukt illustreret værk om reformationsfejringer i Danmark gennem tiderne (Bach-Nielsen 2015). I bogen vurderer han på de afsluttende sider, at planerne for markeringen af det danske reformationsjubilæum 2017 nedtonede den konfessionelle betydning til forskel fra tidligere jubilæer (ibid., 331-338). Uden at anfægte Carsten Bach-Nielsens vurdering vil jeg imidlertid se fejringen af reformationsjubilæet 2017 som udtryk for et civilreligiøst spor, der fremhæver en kontinuitet i forhold til tidligere

4 Oplysninger om den officielle fejring af reformationsjubilæet i 2017 og præsidiets koordinerende funktion er hentet fra luther2017.dk, med mindre andre kilder er angivet. 
reformationsjubilæer i Danmark, snarere end et brud. Min civilreligiøse fortolkning af Bach-Nielsens materiale er i øvrigt i en vis samklang med den teologiske kontekst, som Bach-Nielsen sætter reformationsfejringerne ind i, nemlig som udtryk for "et frelseshistorisk credo, hvor man takker Gud for reformationen, der gjorde Danmark fri af pavekirken" (ibid., 339-341).

Jeg vil først vise, hvordan fejringerne af reformationen fra 1600-tallet og til i dag understreger den civilreligiøse side af den evangelisk-lutherske kirke i Danmark. ${ }^{5}$ Det vil dog føre for vidt at omtale alle de jubilæumsfester, som Bach-Nielsen har medtaget, og jeg valgt primært, men ikke udelukkende at behandle de 'store' hundredårsjubilæer: 1617, 1717, 1817, 1917, som er sammenlignelige med 2017-fejringen. Derefter vil jeg diskutere forskellige eksempler på gennemførte begivenheder ved reformationsjubilæet 2017. Jeg vil dermed vise, at selv om den eksplicitte tak til Gud for at bringe reformationen til Danmark ikke længere er fremtrædende, drejer ritualiseringen af reformationsjubilæerne sig stadig om bevarelsen af Danmark og et håb om fremgang og lykke for det danske samfund.

\section{Civilreligion i korthed}

Det religionssociologiske begreb civilreligion er inspireret af filosoffen Jean-Jacques Rousseaus (1712-1778) tanker om en samfundsreligion, religion civile. Denne samfundsreligion skulle i en tolerant form lære borgerne at elske deres fædreland og de forpligtelser, som det medførte at være borger i landet (Rousseau 1987, 237-238). Rousseaus civilreligion er en religiøs legitimering af nationen som politisk enhed.

En integrerende og moral-oppebærende samfundsreligion kan spores tilbage til antikken. Den romerske kejserkult var en forpligtende dyrkelse af imperiet, hvor borgerne viste deres troskab over for det romerske imperium ved at ofre til kejserens billede. Kejserkulten havde civilreligiøs karakter i rousseausk forstand, fordi den foreskrev forpligtelserne som samfundsborger, mens den i princippet ikke kerede sig om private religiøse anskuelser, så længe de ikke var en trussel mod staten.

Den moderne forskning i civilreligion blev indledt af den amerikanske religionssociolog Robert N. Bellah. ${ }^{6} 1967$ skrev han en banebrydende artikel, hvor han genoptog Rousseaus gamle diskussion om nødvendigheden af, at der blandt borgere skal herske et vist minimum af enighed om samfundsmoralen, for at samfundet kan være levedygtigt (Bellah 1967). Denne enighed skal være hævet over dagens politik, og civilreligionen sikrer dette ved at forlene den grundlæggende samfundsmoral og samfundsorden med religiøs autoritet.

5 Jeg har tidligere omtalt de historiske reformationsfejringer og nogle af de planlagte fejringer i Religion. Tidsskrift for Religionslærerforeningen for Gymnasiet og HF (Warburg 2017). Den følgende omtale af de historiske fejringer er i store træk nedkortet i forhold til artiklen i Religion. Jeg har desuden publiceret en engelsksproget artikel om reformationsfejringerne i tidsskriftet Journal of Church and State (Warburg 2018).

6 Hvor ikke andet er angivet, hviler den følgende opsummering af civilreligionsbegrebet på min seneste oversigtsartikel om civilreligion (Warburg 2015). Denne artikel indeholder også en redegørelse for forskningshistorien og den langvarige diskussion om Bellahs civilreligionsbegreb. 
Bellahs ide om en amerikansk civilreligion var et forsøg på at formulere en samlende religiøs forståelse af USA's nationale identitet, som den typisk kom til udtryk i præsidenternes store taler. Bellah så civilreligion som en særlig amerikansk, fælles religionsform i en nation, hvis forfatning lægger vægt på, at der ikke er nogen kirke, som har fortrinsrettigheder i USA. Præsidenterne kunne godt i deres taler henvise til Gud, men det var en gud, som skulle opfattes som fælles for alle religiøse retninger i USA.

Senere forskning har vist, at der også er civilreligion i lande, der som Danmark har en national kirke. Civilreligion i Danmark er ofte forbundet med folkekirken, men ikke altid, og i de senere år har danske forskere afdækket en rig variation af eksempler på civilreligion i Danmark også uden for folkekirken (Warburg, Larsen \& Schütze 2013).

Civilreligion ligner anden religion ved at have myter, ritualer, kultsteder, tekster osv.; men civilreligion er speciel ved at referere til nationen og landet som noget, der har en særlig, trans-empirisk bevågenhed. Civilreligion hviler således på en påstand om, at der består et særligt forhold mellem nationen og Gud. Civilreligion er ikke en verdslig erstatning for religion; den har en religiøs natur forstået på den måde, at den refererer til det transcendente, som regel Gud, hvor "Gud" repræsenterer det højeste/eneste guddommelige princip for de fleste religioner.

Bellahs oprindelige artikel fra 1967 åbnede op for en diskussion om, hvorvidt civilreligion var en religionsform, hvis indhold primært blev formuleret og formidlet gennem statsapparatet, eller om den også afspejlede et folkeligt værdifællesskab udtrykt i nationalt-religiøse termer (Cristi 2001, 114-136; Warburg 2008). Den første fortolkning anlægger et rousseausk syn på civilreligion, mens den anden har et durkheimsk; begge fortolkninger lægger dog vægt på civilreligionens integrative funktion. De to udtryksformer for civilreligion er efter min opfattelse ikke hinandens modsætninger, men skal ses som komplementære (Warburg 2008). Dette er også tydeligt at se i de danske fejringer af reformationsjubilæer gennem historien. Organiseringen fra oven, som er den rousseauske synsvinkel, er administrativt og økonomisk nødvendig, mens deltagelsen fra neden er essentiel for at give begivenheden den folkelige legitimitet, som den durkheimske fortolkning af civilreligion lægger vægt på.

\section{Det civilreligiøse spor i de historiske reformationsfejringer}

Reformationens indførelse i Danmark-Norge bliver sædvanligvis sat til 1536, hvor den lutherske Christian III stod som sejrherre i den borgerkrig 1534-1536, der er kendt under navnet Grevens Fejde.

Den 30. oktober 1536 bekendtgjorde Christian III på et stort offentligt møde på Gammeltorv i København, at katolsk tro og katolske gudstjenester nu var forbudt, og at alle gudstjenester skulle være efter lutherske forskrifter. Den nye kirkes forhold blev fastlagt med kirkeordinansen i 1537, som blev til med hjælp fra Luthers nære medarbejder, Johannes Bugenhagen. Samme år blev kongen kronet i Vor Frue Kirke. Dermed var den nye statskirke i Danmark-Norge og det øvrige rige blevet, som BachNielsen har udtrykt det, "en kristen kirke i en kristen stat under en kristen fyrste - 
der er salvet på gammeltestamentelig vis af den lutherske teolog Johannes Bugenhagen" (Bach-Nielsen 2015, 16).

Enheden mellem kirke, stat og konge under Guds nåde var også et gennemgående tema ved den første reformationsfejring i 1617 under Christian IV. Det var Sjællands biskop, Hans Poulsen Resen, som var primus motor i fejringen. Festens overordnede tema var at takke Gud for hans "nåderige førelse af landet og folket"' (Bach-Nielsen 2015, 27). Denne tanke, som i sin kerne er karakteristisk for civilreligion, nemlig at der råder et særligt guddommeligt forsyn for Danmark, genfinder man i alle senere reformationsfejringer.

Resen, som også var universitetets rektor, var opsat på, at reformationsfejringen i 1617 skulle fremstå som en eksemplarisk gengivelse af den rene lutherske lære i Resens version (Lausten 2002, 129-130). Den 31. oktober blev dagen for Luthers teseopslag mindet af universitetet. Den følgende dag, hvor hovedfesten blev afholdt, gik kongen sammen med rigsrådets medlemmer og anden højere adel i procession til Københavns Katedral. Biskop Resen prædikerede og afsluttede ved at recitere sin nyskrevne taksigelsesbøn. Denne bøn, som skulle siges i alle kirker i kongens riger og lande, bad Gud om at beskytte Christian IV og velsignede den kongelige familie, medlemmer af rigsrådet, andre medlemmer af adelen og højtstående embedsmænd, "Alt med hensyn til kirkens vel og rigernes og landes velfærd og rolighed" (BachNielsen 2015, 26). Det var først fremmest den rosseauske dimension i dansk civilereligion, der her blev fremhævet, og der er ikke meget, der tyder på, at man fra Resens side tilstræbte durkheimske, folkelige initiativer i forbindelse med fejringen.

Den danske konge var gennem 1600- og 1700-tallet blandt de førende lutheranske fyrster i Europa, og det afspejlede sig i den pragt og selvfølelse, hvormed den enevældige kong Frederik IV styrede fejringen af reformationsjubilæet i 1717 (ibid., 51$58)$.

Til brug ved reformationsfestens højdepunkt med højmesse og aftensang i Vor Frelsers Kirke, den 5. november 1717, havde præsten Hans Thomsen Trojel forfattet en evangelisk jubelsang, hvor Danmark og kongen takker Gud for reformationens velsignelser. Det er en renlivet civilreligiøs lovprisning af Gud og Kristus som tak for, at Danmark var blevet luthersk og fortsat var det. Første strofe lyder (ibid., 60):

$$
\begin{aligned}
& \text { Danske Sion! Vær nu glad } \\
& \text { Ved Lutheri Morgenrøde; } \\
& \text { Lysets Straaler giennembrøde, } \\
& \text { Der du udi Mørket sad: } \\
& \text { Nu i Søndags Luthers Lære } \\
& \text { Fyldte Tvende Hundred Aar, } \\
& \text { Christo være evig Ære, } \\
& \text { At det Lys saa stadigt staaer. }
\end{aligned}
$$

I strofe 7 har forfatteren ladet Gud udsende en profet, Martin Luther, som såede et mannakorn. Da det spirede i Danmarks jord, blev landet med Kong Christian III's mellemkomst renset for den romerske surdej (dvs. katolicismen) (ibid., 60):

Dette Himmel-faldne Man

Fuldmoent blef i Danner-Marken, 


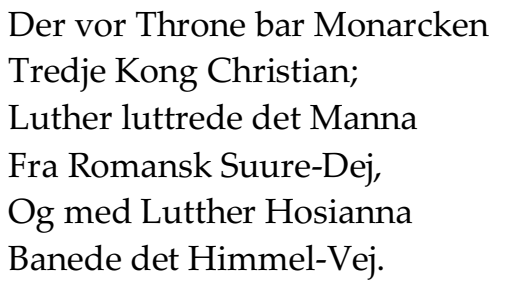

Reformationsfejringen i København i 1717 var topstyret ned til mindste detalje, mens festerne i de store provinsbyer var lokalt organiseret af byråd og biskopper i fællesskab. Især var Ålborg by og stift meget aktive; her blev der gennem en hel uge afholdt taler, deklamationer, festgudstjenester og festmiddage, hvor adel, borgere og håndværkere fejrede reformationen (ibid., 70). Alt i alt var der i Ålborg og flere andre byer et betydeligt durkheimsk indslag i den enevældige konges ellers rosseauske selvfejring, og det tolker jeg som, at denne civilreligiøse manifestation var succesfuld i retning af at samle folket - $\mathrm{i}$ hvert fald i byerne.

I 1817 tog Sjællands biskop, Friederich Münter, initiativ til festen og fik Kong Frederik VI til at annoncere fejringen med en anordning. Heri gjorde kongen vitterligt i erkendelse af det gode, som den rene evangeliske lære havde tildelt fædrelandet at Alherren skulle takkes ved offentlig lovsang og pris, "fordi han giorde saa vel mod Landets Slægter" (ibid., 110). Igen et civilreligiøst udsagn fra højeste sted. Der blev udarbejdet en udførlig drejebog for de tre festdage, og det blev anført som vigtigt, at den almindelige mand blev bekendt med reformationen. Alle almueskoler fik et kort skrift om reformationen til uddeling (ibid., 111-116). Hovedgudstjenesten og festen omkring den blev da også et folkeligt tilløbsstykke.

I det hele taget blev festen i 1817 mere folkelig end de foregående reformationsjubilæer, og mens festlighederne i København og andre store byer var centralt planlagte, så var fejringerne i landsbykirkerne arrangeret i sognene efter opfordring i den kongelige anordning (ibid., 131-133). Den durkheimske komponent i reformationsfejringerne, nemlig den folkelige opbakning, blev således styrket i enevældens sidste år.

Med grundlovens indførelse i 1849 og omdannelsen af statskirken til den evangelisk-lutherske folkekirke indledtes en proces, hvor dansk civilreligion fandt udtryksformer også uden for folkekirken (Warburg 2013). Ved nogle af reformationsfejringerne blev den religiøse side fremhævet, andre gange den nationale, og de enkelte begivenheder foregik ikke altid i folkekirkeligt regi.

Fejringen af 400-året for Luthers fødsel i 1883 var den første fejring efter grundlovens indførelse. Markeringen var fortrinsvis et kirkeligt initiativ, hvor hovedtemaet var et angreb på katolicismen snarere end en national fejring (Bach-Nielsen 2015, 212227). Det gav ind imellem anledning til ganske saftige udfald, som for eksempel denne lidet økumeniske indledning til en kollektbøn trykt i København (ibid., 212):

\footnotetext{
Almægtige, himmelske Fader! Vi takke dig, at Du har ladet Morten Luther fødes til et Vidne mod Pavedømmets Forførelser og sendt ham og hans Medstridere som Ørne over Aadslet!
} 
1917-festen fandt sted på et kritisk tidspunkt under Første Verdenskrig, hvor de stridende magter var låst i blodige og udmattende kampe, uden at en definitiv afgørelse var i sigte. Som led i den nationale mobilisering på hjemmefronten i Tyskland blev Luther benyttet i den interne tyske propaganda; blandt andet blev han omtalt som "Der deutscheste Mann, den es je gegeben hat" (Kronenberg 2014). Man var derfor fra dansk side betænkelig ved at lægge sig for tæt op af den tyske fejring af hensyn til forholdet til Frankrig og England, men hvis man valgte ikke at afholde jubilæet kunne det opfattes som en fornærmelse af Tyskland. Imidlertid blev de tyske reformationsfester aflyst på grund af krigssituationen, og det betød, at man i Danmark kunne tillade sig at afholde en større reformationsfejring og med fokus på den danske lutherske arv (Bach-Nielsen 2015, 234-238). Fejringen blev arrangeret af Sjællands biskop og kirkeministeriet, og det forblev stort set en kirkelig affære, bortset fra at dagen også blev markeret som en offentlig skolefridag (Bach-Nielsen 2015, 236-237).

Med 1936-festen (400-året for den danske reformation) lykkedes det imidlertid at få en bredere, folkelig festligholdelse ikke mindst takket være initiativer fra Københavns kommune i samarbejde med folkekirken (ibid., 269-313). Der blev også i den anledning udgivet en serie reformationsfrimærker med et portræt af Hans Tausen (ibid., 312). Siden sidst i 1800-tallet var Hans Tausen efterhånden blevet etableret som reformationens danske faderskikkelse, især på initiativ af grundtvigske kredse. Hans Tausen havde blandt andet det fortrin, at han ikke var tysker eller naturaliseret indvandrer, men en kernedansk fynbo (ibid., 227-229).

Støtten fra kirkeministeriets side var i øvrigt betinget af, at det skulle være "en folke- og kirkefest" (ibid., 274). Vi ser her en betoning af, at kirke og stat ikke mere er sammenfaldende efter grundlovens indførelse i 1849, og at reformationsfejringen skulle afspejle dette forhold. Det går igen i fejringen i 2017, hvad der blandt andet fremgår af et aktstykke med en bevilling på 2 millioner kroner fra kulturministeriet. Bevillingen angik støtte til den samfundsmæssige fejring af reformationen, idet det var understreget, at "fejringen af reformationsjubilæet er organisatorisk inddelt i to søjler", henholdsvis den folkekirkelige og den kulturelt-samfundsmæssige. ${ }^{7}$

I årene efter Anden Verdenskrig markerede man i 1967 450-året for indledningen til reformationen i 1517, i 1983 var det 500-året for Luthers fødsel, og i 1986 450-året for den danske reformation i 1536. Der blev ved alle markeringer holdt festgudstjenester over hele landet, der var en del presseomtale, og der blev udgivet forskellige bøger og festskrifter (Bach-Nielsen 2015, 242-247). Sammenlignet med tidligere fejringer - ikke mindst under enevælden og fejringen i 1936 - blev disse jubilæer dog ikke de helt store og bredtfavnende begivenheder.

Det var der til gengæld lagt op til ved reformationsfejringen i 2017.

\section{Reformationsjubilæet i 2017}

Når man går ind på reformationsjubilæets hjemmeside luther2017.dk og derudover søger på nettet, bliver man næsten overvældet af, hvor mange arrangementer, der er 
oplistet. Jeg har som nævnt optalt som minimum omkring 1100 enkeltarrangementer, og jeg ved, at nogle af dem har tiltrukket et stort publikum. Men der foreligger ikke noget samlet materiale til at bedømme, hvor mange, der i Danmark rent faktisk har deltaget i reformationsfejringerne i 2017.

Mange arrangementer blev til ved et samarbejde mellem kirke, civilsamfund og kommunale institutioner, og på den måde viste arrangørerne, at reformationen ikke bare var et kirkeligt anliggende, men noget der angik det danske samfund bredt.

\section{Eksempler på lokale jubilæumsarrangementer}

I Kolding Provsti afholdt man på selve reformationsdagen den 31. oktober et arrangement, hvor Koldinghus, Kolding Gymnasium og Sankt Nicolai Kirke i fællesskab markerede 500-året for reformationen med, hvad de i indbydelsen kaldte et "brag af en aften": Først var der en samtalesalon om Luthers tanker om uddannelse og dannelse arrangeret af teatertruppen Mungo Park. Så gik man over i kirken, hvor der blev afholdt en gudstjeneste "helt i Luthers ånd". Her deltog ca. 300 mennesker. Efter gudstjenesten kunne man gå op til det oplyste Koldinghus, hvor der blev åbnet en ny udstilling i Chr. III's kapel med blandt andet en række korte videoer om reformationen, som gymnasieeleverne havde lavet. Omkring 150 mennesker deltog, hvilket var tre gange så mange, som arrangørerne havde forventet. ${ }^{8}$

Her skal man lægge mærke til, at der var tilrettelagt et forløb, hvor der indgik en gudstjeneste, en vandring op mod et vigtigt nationalt monument, nemlig Koldinghus, og et besøg på et centralt erindringssted for reformationen i Danmark, idet reformationskongen Christian III døde på Koldinghus i 1559. Den indledende samtalesalon og gudstjenesten satte den religiøse og historisk-nationale del af arrangementet ind i en moderne dansk kontekst om kultur og identitet, og derved fik hele forløbet en tydelig civilreligiøs karakter. Det var den durkheimske komponent i dansk civilreligion, som her blev manifesteret, idet initiativet og genemførelsen var rent lokalt, og arrangementet var ikke engang annonceret på den fælles, statslige portal, luther2017.dk.

Den 11. maj arrangerede de danske skoler i Sydslesvig en fire timers Luthervandring gennem Slesvig by for over 600 elever fordelt på 12 grupper (Meldgaard 2017). Her mødte de Martin Luther, da han lovede Gud at gå i kloster under et slemt tordenvejr, da han gjorde sig overvejelser om at oversætte bibelen til tysk, og da rigsdagen i Worms dømte ham fredsløs. Katharina von Bora, Luthers hustru fortalte desuden om sit liv. Eleverne prøvede også at trykke salmeblade på en ægte Gutenberg trykpresse og slå teser op på kirkedøren. Det bemærkelsesværdige ved dette arrangement var dets nationale karakter - altså at Luther-fejringen blev forbundet med det danske. Ud fra et konfessionelt synspunkt kunne det jo godt have været et fælles arrangement med nogle tyske skoler. Også her er der tale om et primært durkheimsk udtryk for civilreligion.

8 Alle oplysningerne er fra telefoninterview med pastor Martin Rønkilde, Sanct Nicolai Sogn, Kolding, 10. november 2017 samt fra provstiets folder om reformationsfejringerne i provstiet, www.koldingprovsti.dk/wp-content/uploads/2016/11/LutherKatalog.pdf. 
De efterfølgende eksempler viser gennemgående, hvordan reformationsfejringerne landet over typisk frembød en komplementær blanding af rousseauske og durkhemiske komponenter. Aarhus fejrede for eksempel selve reformationsdagen den 31. oktober 2017 med en lang række arrangementer, dels som et led i profileringen af Aarhus som europæisk kulturby, dels under Rethink Reformation, et samarbejdsprojekt mellem Folkeuniversitetet, Aarhus Domkirke og Aarhus Universitet. ${ }^{9}$ Jeg overværede i en del af disse arrangementer, blandt andet Historisk talkshow, hvor Martin Luther i skuespiller Bjarne Henriksens skikkelse blev interviewet af Niels Krause-Kjær fra DR2's Deadline. Talkshowet blev opført to gange den dag for fulde huse i Aarhus Teater (700 pladser), og showet var i løbet af oktober-november desuden på turné i København, Sønderborg, Odense og Ålborg.

I et civilreligiøst perspektiv var noget af de mest interessante, at Folkeuniversitetet fik arrangeret en lang række workshops, hvor deltagerne mødtes for at formulere moderne teser med visioner om fremtiden for det danske samfund. Disse workshops havde således det dobbelte formål dels at minde befolkningen om Luthers 95 teser, som igangsatte en afgørende religiøs forandringsproces i Europa, dels at sætte fokus på det danske samfunds fremtid. Teserne blev indsamlet løbende, og udvalgte af dem blev projiceret op på Aarhus Teaters facade om aftenen den 31. oktober, som jo er selve reformationsdagen. Ved at trække en parallel mellem de moderne teser og Luthers teser om menneskers forhold til Gud, fik projektet en så stærk religiøs konnotation, at det er rimeligt at karakterisere det som et civilreligiøst projekt.

Aftenprogrammet i Aarhus sluttede med en halv times aftengudstjeneste i domkirken. Jeg talte omkring 350 deltagere, hvilket er et højt tal og vidner om en bred deltagelse. Alt i alt vurderede Folkeuniversitetet, at omkring 7.000 mennesker deltog i de forskellige arrangementer den 31. oktober. ${ }^{10}$

Også hverdagen i 2017 skulle erindre befolkningen om Luther og reformationen. Lagkagehuset i Haderslev lancerede en lagkage med Luther-rosen som dekoration, og fire stifter, Ålborg, Ribe, Fyens og Viborg stifter, gik i samarbejde med lokale bryggerier, som lancerede særlige reformationsøl (Warburg 2017). I Ålborg stifts brochure om reformationsøllet gøres der grundigt rede for den lutherske reformation og naturligvis også for Luthers positive forhold til øl og bryggerierhvervet, idet der står: "Grundlæggende var Martin Luther af den opfattelse, at Gud havde givet mennesker næringens to grundformer i kornet, nemlig brødet og øllet". ${ }^{11}$ Derudover var der en Philipp Melanchton-øl og en Katharina von Bora-øl i sortimentet, og det fremhævedes om hende, at hun udover hendes andre fortræffeligheder var en talentfuld brygmester.

I Viborg lancerede stiftet og Viborg Bryghus en Hans Tausen øl og en Dorothea øl (Dorothea Sadolin var Hans Tausens første kone), foruden den stærke Luther-øl. Vi

9 Oplysningerne om Folkeuniversitets aktiviteter i forbindelse med reformationsjubilæet kan hentes på https://reformation.fuau.dk/.

10 Fra e-mail-korrespondance 3.-8. november 2017 med Anne Engedal, projektleder ved Folkeuniversitetet.

11 http://aalborgstift.dk/udvalg/reformationsudvalg/nyheder/reformationsol/ 
kan se, hvordan Aalborg understregede den guddommelige forbindelse til øl i formidlingen af Luthers reformation, mens Viborg slog på de nationale strenge med den danske reformationsskikkelse Hans Tausen og hans hustru, som imidlertid ikke havde lod og del i 1517-begivenhederne. På sin vis illustrerer de to serier reformations-øl fra Aalborg og Viborg hvordan reformationsfejringerne svinger mellem det kirkelige og det nationale. Viborgs program for reformationsfejringen understregede i det hele taget en gennemgående dansk vinkel på reformationen, hvor Viborg udnævnte sig selv til "Danmarks vigtigste reformationsby". ${ }^{12}$

\section{Nationale reformationsfejringer}

Reformationsfejringen i Danmark bestod dog ikke kun af lokale arrangementer. De vigtigste nationale begivenheder var den officielle reformationsgudstjeneste den 4 . juni samt folketingets højtidelighed i Landstingssalen på selve reformationsdagen, den 31. oktober. I ugen omkring den 31. oktober sendte Danmarks Radio desuden en hel række indslag om reformationen og afholdt en festkoncert i Danmarks Radios koncertsal.

Jeg vil omtale reformationsgudstjenesten og folketingets højtidelighed lidt nærmere, da de var det officielle Danmarks to vigtigste markeringer af reformationsjubilæet. Desuden kom dansk civilreligion tydeligt til udtryk i begge arrangementer, ikke mindst i statsminister Lars Løkke Rasmussens taler.

\section{Den officielle reformationsgudstjeneste}

Det officielle Danmark afholdt sin reformationsgudstjeneste pinsedag, den 4 . juni 2017 kl. 14 i Haderslev Domkirke. Den blev vist i fjernsynet, så hele Danmark kunne overvære den. ${ }^{13}$ Haderslev er et vigtigt erindringssted for reformationen, for reformationen blev reelt indført i Sønderjylland allerede i 1526, da Christian III var hertug af Nordslesvig. I gudstjenesten deltog kongehus, regering og de danske biskopper samt en lang række indbudte honoratiores. Arrangementet var en klar videreførelse af de store festgudstjenester ved de tidligere jubilæer i 1617, 1717, 1817 og 1917, og gudstjenesten markerede den samme nationale enhed af monarki, kirke og øvrighed som tidligere.

Gudstjenesten var i sin grundstruktur naturligvis en pinsegudstjeneste, men med direkte og indirekte referencer til Luther, både i salmevalg og i biskop Peter SkovJakobsens prædiken. Men i modsætning til tidligere reformationsfejringer var denne gudstjeneste noget mere inklusiv, idet der var givet plads til, at blandt andet lederne af baptisterne og den katolske kirke i Danmark kunne fremsige hver sin bøn som en del af kirkebønnen.

At invitere netop disse to historiske arvefjender af den evangelisk-lutherske kirke indenfor var bemærkelsesværdigt. Katolikkernes tilstedeværelse markerede et klart

12 Viborgs jubilæumsbrochure på 12 sider kan hentes på http://www.e-pages.dk/jfmadhoc/23/\%20.

13 Kilder til begivenheden er tv-transmissionen, http://www.haderslevdomsogn.dk/reformation samt de trykte udgaver af biskop Peter Skov-Jakobsens prædiken og statsministerens tale. Se https://kirkenikbh.dk/nyheder/peter-skov-jakobsens-praediken-ved-reformationsgudstjeneste-i-haderslevdomkirke og http://www.stm.dk (under Statsministeren - taler). 
brud med tidligere reformationsjubilæers markante anti-katolske brod, som så malende var udtrykt i for eksempel citaterne fra jubilæerne i 1717 og 1883. Man må give de to historikere, Jes Fabricius Møller og Uffe Østergaard ret, når de konstaterer, at en åben anti-katolicisme ikke længere er en del af dansk identitet, selv om den var til stede så sent som i 1972 i forbindelse med folkeafstemningen om Danmarks tilslutning det Europæiske Fællesmarked (Møller \& Østergaard 2013).

I reformationsgudstjenesten deltog desuden overrabbineren samt landsformanden for muslimske organisationer. Deres tilstedeværelse betonede yderligere gudstjenesten som en samlende national-religiøs begivenhed - hvilket netop er karakteristisk for civilreligion.

Efter selve gudstjenestens afslutning holdt statsministeren en tale fra en talerstol, der var stillet op foran alteret. Her gav han sin opfattelse af Luthers betydning for det danske samfund. Han endte med en parafrasering over Grundtvigs pinsesalme: "I Grundtvigs salme stråler solen på os i al sin glans. Med kærlighed. Oplysning. Frihed og ansvar". I salmen er solen både den fysiske sol og et symbol på Jesus, så når statsministeren talte om en sol, der skinner på os med kærlighed, så hentydede han til Jesus. Det er således gennem Jesus, at danskerne fik oplysning, frihed og ansvar. Det er en klar civilreligiøs tanke. Med afslutningsordene: “Til lykke til Folkekirken. Til lykke til Danmark" fik statsministeren desuden markeret samspillet mellem reformationsfejringens to søjler, den folkekirkelige og den kulturelt-samfundsmæssige. Hele forløbet, både selve gudstjenesten og statsministerens tale var en klar iscenesættelse fra oven, altså en rosseausk tilgang.

\section{Folketingets højtidelighed i Landstingssalen}

Ved folketingets højtidelighed den 31. oktober deltog kongefamilien, statsministeren og andre medlemmer af regeringen, medlemmer af folketinget samt en række indbudte gæster fra den akademiske verden og fra folkekirken. ${ }^{14}$ Højtideligheden blev transmitteret over folketingets interne tv. Programmet bestod af en velkomsttale af folketingets formand Pia Kærsgaard, af Dronningens tale, af statsminister Lars Løkke Rasmussens tale samt af forskellige musikalske indslag.

Statsministerens tale tog udgangspunkt i Luthers berømte skrift Om et kristenmenneskes frihed (Luther 2016). Herfra citerede han det kendte, indledende diktum:

Et kristent menneske er en fri herre over alle ting, og ingen undergivet. Et kristent menneske er en villig tjener $i$ alle ting, og alle undergivet. ${ }^{15}$

Det var ord, som statsministeren sagde, han holdt meget af, fordi de sagde noget om balancen mellem det enkelte menneske og fællesskabet. Statsministeren uddybede

14 Kilder til begivenhed er tv-transmissionen fra folketingets tv samt de trykte taler. Talerne kan hentes på: http://www.ft.dk/da/organisation/formanden-og-praesidiet/formandens-taler/folketingets-formands-tale-til-reformationsjubilaet-2017; http://kongehuset.dk/nyheder/hm-dronningens-tale-vedden-officielle-markering-af-reformationsjubilaeet-den-31-oktober-2017-i; http://www.stm.dk (under Statsministeren - taler).

15 Ordene er gengivet fra talemanuskriptet. Der verserer forskellige, let afvigende oversættelser til dansk. I Wiwes nye oversættelse (Luther 2016, 31) er ordlyden: “Et kristenmenneske er en fri herre i alle forhold, og ingen underlagt. Et kristenmenneske er en tjener i alle forhold, og enhver underlagt." 
gennem resten af talen disse ord i hans tanker om frihed, kritisk tænkning og uddannelse for alle i Danmark i dag. Han konkluderede:

Vi skal gøde de frø, Luther såede for 500 år siden. Det frie menneske. Det fælles ansvar. Den kritiske tanke. Uddannelse af hele folket. Det er grundlæggende værdier, som det er vores opgave at føre videre.

Med al den tyngde og autoritet, som statsministerembedet besidder, fortolkede Lars Løkke Rasmussen således Luthers opfattelse af, hvad det vil sige at være et kristent menneske og knyttede disse ord til udfordringer i dagens danske samfund. Dette er tydeligt civilreligion fra oven, altså en rosseausk civilreligion.

\section{Konklusion}

Det er interessant, at fejringen af reformationsjubilæet i 2017 har haft en så stærk fokus på det nationale frem for det konfessionelle, når man sammenligner med fejringerne i Norge og Sverige. Den særlige danske, nationale, kulturelle og samfundsmæssige vinkel på den lutherske reformation er et vidnesbyrd om, at regeringen - og mange andre med den - delte tanken om, at reformationen har haft en gennemgribende betydning for det danske samfund, som det ser ud i dag. Rækkevidden af denne påstand bliver som sagt diskuteret $\mathrm{i}$ fagkredse.

Ved at analysere reformationsjubilæerne som udtryk for dansk civilreligion kan den nationale betoning af reformationsfejringen også ses som et udtryk for, at reformationen i Danmark synes at spille en nationsopbyggende mytologisk rolle, hvor Gud står i et særligt forhold til Danmark. Det er en tanke, som man blandt andet genkender fra Grundtvigs nationalistiske historiefilosofi. Grundtvig mente blandt meget andet, at i Guds øjne var danskerne "det sande hjertefolk", og Grundtvig gav hermed "danskerne en særlig udvalgt rolle i Guds plan med folkenes skabelse" (Vind 1999, 167-168). Den opfattelse er efter min opfattelse ikke helt fraværende i dag, om end nok i det skjulte. For som Herbert Pundik angiveligt skulle have sagt ironisk: "Danskerne er et udvalgt folk. De ved det bare ikke, og det er deres held." 


\section{LITTERATUR}

Bach-Nielsen, Carsten

2015 Fra jubelfest til kulturår. Danske reformationsfejringer gennem 400 år, Aarhus Universitetsforlag, Aarhus.

Bellah, Robert N.

1967 "Civil Religion in America", Drdalus, 96, 1-21.

Cristi, Marcela

2001 From Civil to Political Religion. The Intersection of Culture, Religion and Politics, Wilfrid Laurier University Press, Waterloo.

Frederiksen, René \& Claus Bo Hansen

2017 Præsidiet for Reformationsjubilæet 2017. Effektmåling før og efter, A\&B Analyse, Odense (tilgængelig under luther2017.dk - præsidiet).

Herbener, Jens-André P.

2017 Luther. Antidemokrat og statsidol, U Press, København.

Kaspersen, Lars Bo \& Johannes Lindvall

2008 "Why No Religious Politics? The Secularization of Poor Relief and Primary Education in Denmark and Sweden", Archives Européennes de Sociologie 49, 119-143.

Knudsen, Tim

2000 “Tilblivelsen af den universalistiske velfærdsstat", in: Tim Knudsen, ed., Den nordiske protestantisme og velfærdsstaten, Aarhus Universitetsforlag, Aarhus, 20-64.

Kronenberg, Martin

2014 Kampf der Schule an der "Heimatfront" im Ersten Weltkrieg: Nagelungen, Hilfsdienste, Sammlungen und Feiern im Deutschen Reich, Disserta Verlag, Hamburg, 223-225.

Luther, Martin

2016 Om et kristenmenneskes frihed. Åbent brev til Pave Leo X. De 95 teser om aflad. Oversat med indledning og kommentarer af Carl Frederik Wiwe, Systime, Aarhus.

Meldgård, Anne

2017 "Luthervandring i Slesvig", NYT - Danske Sømands- og Udlandskirker 14 (3), 16-17.

Møller, Jes Fabricius \& Uffe Østergård

2013 "Lutheran Orthodoxy and Anti-Catholicism in Denmark 1536-2011", European Studies 31, 165189.

Nielsen, Marie Vejrup

2011 "Claiming Luther as a Religious Resource: Civil Religion in Conflict", Journal of Religion in Europe 4, 300-327.

Petersen, Jørn Henrik \& Klaus Petersen

2009 "Religion, kirke og velfærdsstat - er der en sammenhæng? Om velfærdsstatens opståen og udvikling", Religionsvidenskabeligt Tidsskrift 54, 39-65.

Petersen, Jørn Henrik

2017 “Luther og velfærdsstaten", Jyllands-Posten 2. nov., 1. sektion, 25.

Rousseau, Jean-Jacques

1987 Samfundspagten, Rhodos, København.

Stjernfelt, Frederik

2017 Syv myter om Martin Luther, Gyldendal, København.

Vind, Ole

1999 Grundtvigs historiefilosofi, Gyldendal, København.

Warburg, Margit

2008 "Dannebrog: Waving in and out of Danish Civil Religion", Nordic Journal of Religion and Society 21, 165-183. 
2013 "Gud bevare Danmark. Dansk civilreligion i det store og det små”, in: Margit Warburg, Signe Engelbreth Larsen \& Laura Maria Schütze, ed., Civilreligion i Danmark. Ritualer, myter og steder, Forlaget Univers, Højbjerg, 7-53.

2015 “Civilreligion”, in: Armin W. Geertz \& Tim Jensen, ed., Religionsforskningen før og nu. Nyere tid, Gyldendal, København, 605-615.

2017 “Reformationsjubilæerne i Danmark i en civilreligiøs fortolkningsramme", Religion. Tidsskrift for Religionslærerforeningen for Gymnasiet og HF, no. 1, 16-28.

2018 "The Danish Reformation Celebrations as Civil Religion", Journal of Church and State, https://doi.org/10.1093/jcs/csy030.

Warburg, Margit, Signe Engelbreth Larsen \& Laura Maria Schütze, ed.

2013 Civilreligion i Danmark. Ritualer, myter og steder, Forlaget Univers, Højbjerg.

Østergaard, Uffe

2003 "Lutheranismen, danskheden og velfærdsstaten", in: Klaus Petersen, ed., 13 historier om den danske velfærdsstat, Syddansk Universitetsforlag, Odense, 27-36.

Margit Warburg, professor, dr. phil.

Institut for Tværkulturelle og Regionale Studier, Københavns Universitet warburg@hum.ku.dk 